\title{
Franchising In China: The Case Of Medicine Shoppe
}

Paul Sheldon Foote, (E-mail: foote@fullerton.edu), California State University, Fullerton Zheman Gao, (E-mail: zhemangao@juno.com), California State University, Fullerton

\begin{abstract}
As franchising becomes more favorable in China, both foreign and local franchisers and franchisees will benefit from the successful business model developed by Medicine Shoppe
\end{abstract}

\section{Introduction}

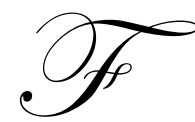

ranchising became a very popular business model in China after the Chinese government opened the door to foreign franchising investors in the 1980's. A number of well-known foreign franchisers such as McDonalds, KFC, Century 21, Medicine Shoppe and Starbucks have entered the Chinese market during the past 20 years and are operating very successfully in terms of market shares and profitability. ${ }^{\mathrm{i}}$

Eastman Kodak's Kodak Express is a very successful example in Chinese franchising industry. The growth rate of its revenues and profit in China was $36 \%$ and 58\%, which is very impressive comparing its global growth of $5 \%$ and $13 \%$ in $1999^{\text {ii }}$. Now, every three days, a franchise store will be opened in China.

Another example of a successful foreign franchise is Tricon Global restaurant, a US based restaurant. Since the opening of its first store in Beijing in 1987, Tricon has been growing into a global food giant with more than 800 KFC outlets and 100 Pizza Hut restaurants in China now. ${ }^{\text {iii }}$ In 1996, a KFC restaurant in Shanghai set a record RenMingBi(RMB) 400,000 (exchange rate: $\$ 1=8.26 \mathrm{RMB}$, US $\$ 48,426.00$ ) in daily sales. Another subsidiary of Tricon, QianMen restaurant in Beijing, set a margin record of RMB 445,000 (US\$53,847.00) on Oct 11997 in profit; that is 100 times that of domestic restaurants' average margin ${ }^{\text {iv }}$. These numbers prove that the performance of Tricon's franchising model is very impressive.

Based on the above examples, one can see that for certain industries, franchising has been very successful in China. However, in other industries, it is not that easy to be successful due to the complexity of those industries. In this article, we will explain how complicated industries, such as the pharmaceutical industry, can operate successfully in China by analyzing Medicine Shoppe's franchising operation in China.

\section{The Need to Move Abroad for US Franchising Industries}

According to a survey by US Department of Commerce, the survival rate for franchising enterprises in the US is much higher than none-franchising industries. ${ }^{v}$ Since about $60 \%$ of business in the US is coming from franchising industries, we can see that franchise enterprises are more successful than non-franchise enterprises.

Even though the US franchising industry is very successful, it has reached saturation in the domestic market, while in most developing countries, franchising is still in the growth stage. Expanding business overseas is becoming a necessity for US companies.

When US franchisers first moved overseas, they targeted most European countries, Australia, and Canada, because of the same language and similar legal and cultural background. ${ }^{\text {vi }}$ Research shows that similar cultural background will make it easier for a franchiser to expand into a foreign country successfully. ${ }^{\text {vii }}$ For example, in terms of sales revenue, US based franchise stores are ranked top in Australia. viii 
The success, for most US franchisers, in the future, will depend on whether or not they can enter into developing countries to gain more market shares. The best aspect of franchising in developing countries, such as China, is that US franchisers have unbeatable advantages in information technology and management skills, since US has had many years of experience in franchising industries, whereas franchising is still in the infant stage in developing countries. ${ }^{\mathrm{ix}}$

Many franchisers have entered into developing countries and have had much success. As our research shows, Medicine Shoppe, the biggest pharmaceutical franchise company in the world, has set up over 1,000 stores in Pan Pacific Rim area, which includes Australia, Canada, Taiwan, India, and Indonesia. ${ }^{x}$ The growth rate of the same store sales was $23 \%$ in 2002 for Medicine Shoppe, comparing to $12 \%$ industry average ${ }^{\mathrm{xi}}$. Medicine Shoppe has eyed the Chinese pharmacy market for years; in September 2002, the company began to set up the first foreign brand pharmaceutical franchise store in China. Many analysts believe that Medicine Shoppe China will help greatly to reshape the structure of the Chinese pharmacy retail market in next few years.

What were the driving factors for Medicine Shoppe to move into Chinese market? Several internal and external factors make the Chinese pharmaceutical market a very attractive area for franchisers.

\section{The Reform on Separation of Medicine Retail Distribution from Hospitals in China}

Before 1978, the Chinese economy was in the communist economic mode. At that time, everything was under the control of the central government. In the health area, the Ministry of Health P. R. China was the control center.

For years, the retail distribution of medicine in China was controlled by the hospitals. All prescriptions were sold to patients by the hospitals directly; retail drug stores sold over-the-counter (OTC) drugs only.

The shortcoming of the hospital distribution system is that the price for medicine to the end users is too high, because more layers of distribution have been added. Usually, medicine manufacturers mark up 15\% when selling their products to medicine distributors, distributors then mark up $20-25 \%$ when selling to hospitals, hospitals will then add up $10 \%$ when selling to patients. ${ }^{\text {xii }}$

The other pitfall of the hospital distribution system is that hospitals could take advantage of being the unique source for prescription drugs, because patients had to buy medicines in hospitals where prescriptions were given.

For hospitals and doctors, a large portion of the sale of medicine would be profit. Therefore, the hospital distribution system ends up with doctors prescribing patients higher-margin medicines with high priority. This does help hospitals make more money, and doctors will receive a certain percentage of the medicine sold to the patients as a bonus from the hospitals.

The combination of hospital and medical distribution system also creates problems such as kickbacks. When medical distribution agents and medical manufacturers promote their products, they will first persuade doctors, then doctors will decide what kind and how much medicine hospitals need to order, once related supervisors in the hospital approve the requests. When hospitals actually place the order with the manufacturers, doctors and supervisors will get a commission. In the whole process, doctors and hospital managers are benefiting at the cost of their patients.

Under the old medical insurance system, the combination of medical and hospital system worked just fine because patients did not care how high their medical expense were because their employers covered all of their medical cost sooner or later.

After China opened its door to the world in 1978, the country underwent changes in many areas. The biggest change for the country was the transition from a socialist economy to the market oriented socialist economy. 
The transition created changes in the medical insurance system. Because the burden on employers became so large, employers were no longer $100 \%$ responsible for employees' medical expenditure. Therefore, instead of solely relying on employers, medical insurance companies began playing a more important role in the medical system, and more and more patients began to feel the pain of paying for high priced medical expenditures.

The medical distributions by hospitals are under fire and the reform of the medicine retail distribution is inevitable. ${ }^{\text {xiii }}$ The reform called for retail medicine stores to handle the prescription medicine market, rather than the hospitals. During the transition, companies with advanced skills in prescription distribution will have the advantage, and gain more market shares, in the Chinese pharmaceutical retail market.

Our research shows that Medicine Shoppe's advantage in China lies in its 100\% professional distribution of prescription drugs; while in China such skills are not well developed yet.

\section{The Impact of the WTO on Pharmaceutical Franchising in China}

Medicine Shoppe entered into the Chinese market just as the Chinese government began to allow foreign retail pharmacy stores to enter. Medicine Shoppe's experience in the Chinese prescription medical market will help it corner a big chunk of this market.

Before China joined the World Trade Organization (WTO), franchising was prohibited in some industries due to legal and economic factors. Pharmaceutical distribution area was one of the industries on the prohibited list ${ }^{\mathrm{xiv}}$, because the Chinese government wanted to protect its domestic pharmaceutical industry from the competition of foreign companies.

In 1997, the National Industry and Commercial Administration Bureau and the Domestic Trade Bureau announced the Notice of Chain Stores Registration Administration. The notice listed the requirements to set up chain stores; including administration structure, documents required for registration, and procedures for registration. ${ }^{\mathrm{xv}}$ These were the first regulations for franchising industries in China.

As part of the requirements to access the WTO, the Chinese government has developed regulations to remove the barriers, allowing foreign enterprises to enter into the pharmaceutical distribution channels of China. According to the agreement, China would open its pharmacy retail market to foreign investors on January $1^{\text {st }} 2003$. Medicine Shoppe came to China's market in 2002 before the Chinese government began to allow foreign invested franchising stores in retail areas, as a trial franchise.

Most people believe that after 2003, the Chinese pharmaceutical retail market will be fully opened to foreign capital. However, this is just too optimistic. To give domestic enterprises more time to prepare for the competition from foreign investors, there are still limitations on foreign investors that get into the Chinese pharmaceutical retail market. For instance, foreign direct investment can not open more than 30 stores until December $2004^{\text {xvi }}$, but because such limitation does not apply to the Chinese- foreign joint ventures, when Medicine Shoppe found franchisees in China, they used joint venture as an entry model to expand their businesses, and they plans to open about 150 stores by 2004 .

\section{The Entry Strategy for Foreign Franchisers in China}

Many foreign franchising industries are operating in China now and each franchiser holds its own strategy when entering into Chinese market. Some are setting up company-owned stores first, while others are setting up franchising stores directly.

McDonald's entered into the Chinese market in the 1980s and since then it has opened numerous of restaurants in China. However, none of these restaurants are franchising stores; instead they are either joint ventures or company owned stores. After years of successful operation in China, in 2003, McDonald's began to start its franchising stores. 
McDonald's franchising operation is well known throughout the world, but it still used a prudent strategy when entering into the Chinese market. First, it operated company-owned stores; next, it converted successful company-owned stores into franchising stores ${ }^{\text {xvii }}$. This shows that franchising is feasible in the Chinese market.

Kentucky Fried Chicken (KFC) used a totally different approach. When they first moved into China, they began to set up franchise stores, and so far they have over 1000 stores in China. In 2002, KFC was ranked as the top restaurant in China in terms of revenue.

Medicine Shoppe has taken the same approach as KFC. In September 2002, it opened its first store as a joint-venture company, in Shenzhen. One party is the Shenzhen-based Pharmaceutical Enterprises-Nep-Star, the other party is the US-based Pacific Gateway Capital LLP. ${ }^{\text {xvii }}$ After a 6 months trial operation in China, Medicine Shoppe began to open more franchising stores in China. The revenue from these stores has increased since they changed to franchising stores showing that setting up pharmaceutical franchise stores directly in China is feasible.

Internal factors such as medical reforms and external factors such as the WTO related agreement make it possible for foreigners to enter into the Chinese pharmaceutical retail market. The biggest reason for foreign franchise pharmacy stores to enter the Chinese market is because China has a growing market, with great growth potential in pharmaceutical area. ${ }^{\text {xix }}$

\section{The analysis of pharmaceutical retail market in China}

Experts predict that in the next five years, the annual growth rate in drug retail will be $15 \%$. By 2008 , China's drug revenue will rank number 5 in the world, and will create $14 \%$ of the global drug revenue. ${ }^{\mathrm{xx}}$ According to Asia Intelligence, by 2020, China will become one of the largest OTCs markets in the world ${ }^{\text {xi }}$.

With the development of the medical reform in China, pharmaceutical retail stores will play a more important role. More and more domestic pharmaceutical manufacturers have set up their own retail stores.

To regulate the pharmaceutical industry, the Chinese government has passed a series of regulations related to pharmaceutical production and distribution. Good Manufacturing Practice (GMP) and Good Supply Practice (GSP) have very comprehensive effects on all the pharmaceutical related enterprises. So far China has 5,000 pharmaceutical manufacturers, of which only 30\% have passed the GMP certification; Among 700 mid-to-large sized pharmaceutical distribution enterprises, only 15\% have the GSP certification. ${ }^{\text {xii }}$ All manufacturing enterprises needs to pass GMP by June 30, 2004; and all pharmaceutical distribution enterprises have to pass GSP by the end of 2004. ${ }^{\text {xiii }}$ The regulations will prevent mid to small size enterprises from survival because they may fail to meet related requirement.

Mergers and acquisitions in the pharmaceutical area have, in recent years, become more and more popular. ${ }^{\text {xiv }}$ Many enterprises strengthen their power by merger or acquisition or reconstruction. A good example of this practice is Ya Tai Group. Ya Tai formed alliances with Shang Hai Medical and Pharmaceutical Group in 2001, and set up a wholesale distribution channel first and then set up about 500 retail stores in China. ${ }^{\mathrm{xxv}}$ Ya Tai Group has built up its brand name in China since then.

The reorganization of the Shanghai Medical and Pharmaceutical Group was the biggest ever event in China's pharmaceutical industry. The group reorganized its manufacturing, distributing, and marketing, and ranked number one in terms of exporting, manufacturing and distributing in China in 2002. ${ }^{\text {xxvi }}$ Through acquisitions, the Shanghai Medical and Pharmaceutical Group has acquired four traditional Chinese medicine stores that have over 100 years of history, and have helped build the company's brand recognition in the traditional medicine arena. ${ }^{\text {xxvii }}$

Shenzhen 999 Pharmaceutical Company, the only approved pharmaceutical enterprise in China that was permitted to set up national wide retail stores so far, has just joined alliance with one of the biggest Japanese pharmaceutical chain stores, 89 JunZhe Pharmacy, to build the nationwide retail stores in China. ${ }^{\text {xxiii }}$ The joint venture will set up 10,000 stores in next 5 years. 
In China, Chongqing Heping is the biggest pharmaceutical retail store, with 725 stores and yearly revenue of 668 million RMB (US\$80,871,671.00). Shenzhen Haiwang is the second largest pharmaceutical retail store, with 320 stores and yearly revenue of 466 million $\operatorname{RMB}(\mathrm{US} \$ 56,416,465)$. $^{\text {xix }}$

\section{The operation of Medicine Shoppe in China}

Medicine Shoppe in China faces the competition from domestic pharmaceutical manufacturers in the retail areas; but what makes Medicine Shoppe different from domestic manufacturers is their managerial experience and $100 \%$ professional pharmacy skills, such as medical management, the judgment on doctors' prescription, follow- up on patients, consultation and the directions on usage of medicine. ${ }^{\mathrm{xxx}}$

Shenzhen Nepstar holds the majority ownership of Medicine Shoppe China, and it is the first enterprise that received the ISO 9001 certification from the International Standard Organizations in China ${ }^{\mathrm{xxxi}}$. To expand its development, Shenzhen Nepstar spent 1 million US dollars in obtaining the franchising rights from Medicine Shoppe. ${ }^{\text {xxii }}$

After a few months of operation, the gross revenue from four stores in Medicine Shoppe Guangzhou has increased $30 \%$ as a result of the management and technology skills provided by Medicine Shoppe ${ }^{\text {xxxiii }}$. This proves that Medicine Shoppe's successful experience in other countries will lead its success in China.

Medicine Shoppe in China has created a unique way to attract more clients: a combination U.S. and Chinese pharmacy store. First, Medicine Shoppe provided 200 pharmacy technicians from the US as a support to its operation in China. Second, it also provided training to Chinese employees to ensure that they can provide "100\% professional pharmacy" skills to customers. Third, Medicine Shoppe Guangzhou set up an area for "Tong Ren Tang," one of the most well known brands for traditional Chinese medicine, so that they can help customers make traditional Chinese medicine in stores. ${ }^{\text {xxiv }}$

\section{The Local Protectionist in Pharmacy Retail Area}

Local protection is very popular in pharmacy retail area. Some areas have the rules that no more than 10 retail stores can be owned by non-local enterprises ${ }^{\mathrm{xxxv}}$. Every province prevents other province's retail stores from entering into its territory. Every province has the right to approve the set up of pharmaceutical chain stores in that area. When dealing with enterprises from other areas, every province sets up limitations that will prevent the entering of non-local enterprises, as a result the local protectionist will defer the development of pharmaceutical retail industry ${ }^{\mathrm{xxv}}$. ShenZhen's 39 Pharmaceutical has only one store in Beijing. To get the approval to set up a retail store in Beijing, it had to set up a joint venture with a local partner ${ }^{\mathrm{xxx} v i i}$.

Medicine Shoppe selected Shenzhen, Guangzhou and Shanghai as its main target market in China because these areas have less local protection. So far, in Guangzhou, it has 20 branches already.

The local protection will change in the near future. To make its market open and encourage competition, Beijing is issuing a new rule that will open its pharmacy retail market to the whole country. This will set up a model for the whole country and help remove the local protection barriers.

\section{The Availability of Human Resources}

Medicine Shoppe is promoting its " $100 \%$ professional pharmacy" in China, which makes it a standout among its peers. ${ }^{\text {xxxviii }}$ It has onsite pharmaceutical specialists (or technicians) who provide services such as consultation related to OTC and non-OTC medicines. Medicine Shoppe's unique operation in China will bring about the revolution in the pharmaceutical retail industry, ${ }^{\text {xxix }}$ and the need for professional specialist in pharmacy will be increased. 
Currently there are 78,700 certified pharmacy technicians in China ${ }^{\mathrm{xl}}$, and by 2005 , the number will have doubled. ${ }^{\text {xli }}$ So far, certified pharmacy technicians are not playing an important role in the retail industry; instead most of them are working for manufacturers and hospitals. ${ }^{\text {xli }}$

According to the regulations released by the National Medical Administration Bureau, every retail store should have at least one certified medical specialist (or technician) by the end of year 2004. ${ }^{\text {xliii }}$ Even though the number will increase by 35,000 per year, it is hard to meet the demand from pharmaceutical retail stores. ${ }^{\text {xliv }}$

With the rapid growth of franchising industry in China, there is a great demand of human resource. Beijing Normal University, Zhuhai Branch, began to set up franchising department, which is also the first institute that has franchising department in Asia ${ }^{\text {xlv }}$.

\section{Accounting and tax rules for franchise industry in US and China}

\section{Tax rules}

According to the Income Tax for Foreign-Invested Enterprises and Foreign Enterprises of China, foreign enterprises are subject to $20 \%$ as withholding income tax on franchise fee that is generated in the territory of China. The franchise fee refers to revenue from China even though the companies has not established organizations or sites within the Chinese territory, or revenues actually has nothing to do with their organizations' main business activities that has physical location in the Chinese territory. ${ }^{\text {xlvi }}$

However, the $20 \%$ withhold tax is to be reduced to as low as $5 \%$ if the taxation treaty is to be applied between China and the foreign country. ${ }^{\text {xlvii }}$ According to the Article 11 of the Agreement between the U.S. and Chinese government for Avoidance of Double Taxation and Prevention of Tax Evasion with Respect to Tax on Income, the withhold tax should not exceed $10 \%$ of the royalty. ${ }^{\text {xlvii }}$

Besides the withheld income tax mentioned above, the State Administration of Tax (SAT) (www.satc.gov.cn) requires that foreign franchisers pay a 5\% Business Operation Tax on the royalty payment remitted abroad. xlix $^{2}$

\section{Financial and Accounting Regulations} to WTO. ${ }^{1}$

China has its own accounting regulations and is moving to the international regulations after its accession

The Finance and Commercial Administration Bureau of PRC released The Temporary Financial and Accounting Regulations of Chain Store Operation in 1997. According to the regulation, chain stores including franchise stores should follow the following three regulations when they set up their own financial and accounting regulations: The General Financial and Accounting Regulations of Enterprises, The Accounting Standard of Enterprises, and The Financial and Accounting Rules of Commercial Enterprises. ${ }^{\text {li }}$

According to the Financial and Accounting Rules of Commercial Enterprises, intangible assets should be recorded as revenue only when the following two conditions are met: the cost of the intangible asset could be reasonably measured and it is more than likely that the intangible assets will bring in economic benefits for the company. ${ }^{\text {lii }}$ As we can see, franchise fee possess the above two features; therefore, franchise fee is classified as intangible asset by franchisees. ${ }^{\text {liii }}$

Franchisers should record services provided as revenue, if the revenues are from providing preliminary and afterward service, from the transfer of equipments and other tangible assets and/or from transfer of technologies. ${ }^{\text {liv }}$ 
The franchise revenue should be recorded when one of the conditions has been met: when tangible assets or technologies are transferred and when services are provided. All other revenues should be recorded as "deferred revenue".lv

Article 16 of The Financial and Accounting Rules of Commercial Enterprises also says franchisees could pay franchisers no more than $3 \%$ of their revenues as royalty expense and record the expense as administration expense. ${ }^{\text {lvi }}$

Related journal entries are as follows ${ }^{\text {lvii: }}$

1. The accounting for the first franchising fee payment

a. Franchisers

Dr. Cash (or Accounts receivable)

b. Franchisees

Cr. Other incomes - franchising fee

Dr. Intangible assets - franchising right

Cr. Cash ( or Accounts payable)

2. The accounting for ordinary franchising fee other than the first franchising fee payment

a. Franchisers

Dr. Cash (or Accounts receivable)

Cr. Other incomes - franchising fee

b. Franchisees

Dr. Franchising expense

Cr. Cash

Or

Dr. Raw materials

Cr. Cash (or accounts payable)

3. The accounting for advertisement fund

a. Franchisers

Dr. Cash (or accounts receivable)

Cr. Other incomes - franchising fee

b. Franchisees

Dr. Sales expense

Cr. Cash (or accounts payable) China ${ }^{\text {lviii. }}$

There are special regulations for foreign invested enterprises( FEI) on bookkeeping and accounting in

1. Language and Currency base: Renminbi is a required currency base and Chinese is a language base for both ledgers and financial statements for FEIs.

2. Selections of accounting software: Pre-approval is required for FEIs before they can choose any kind of computerized accounting software. The authorization is from the tax bureau or the administration bureau.

3. Audits: Chinese CPA firms are the only authorized party to audit FEIs in China and the auditing is according to the Chinese Auditing Standard.

\section{Benefits of Being Franchisees}

The reason why franchising is so successful is because it has so many benefits that attract investors in the following aspects: 
First, it helps minimize investment risk. To generate a new business model and test it in the real world will take a long time and the result could turn to be very negative in the end. However, by using a franchise model, investors can invest in a successful business model and the chance that the business will lose money is very small ${ }^{\text {lix }}$.

Second, it saves time and cost when building brand recognition. Individual companies would take a longer time, and generate more advertising cost, in building up their own brand. ${ }^{1 \mathrm{x}}$ By using franchise model, franchisees can enjoy the well-known brand recognition right away. As a result, the performance of franchising companies is much better than individual start-up companies.

Third, it avoids "reinventing the wheel". ${ }^{x i}$ Franchisers, especially foreign franchisers, have years of successful experience in management, operations and implementation of information systems. These valuable assets are very important to Chinese franchisees, since most Chinese people lack advanced management and operation skills. For them, franchising is like an "already cooked chicken". Ixii

\section{Potential Investors in Pharmacy Retail Industry in China}

US franchisers need to consider that in order to be successful in the franchising industry in China, the availability of potential investors in pharmaceutical retail franchising is a very important factor. Our research shows the following group of people may be interested in investing on pharmacy retail stores.

First, foreign investors may be interested in it.

According to a survey by BBC News, foreign direct investment in China in 2002 was about $1 / 3$ higher than that in the same period of 2001. Ixiii This impressive figure shows that China is still foreign investors' favorite point. Since the pharmaceutical retail industry has so many opportunities and it would definitely attract foreign investors in this area.

In Medicine Shoppe case, we find venture capital from the U.S can be very interested in the pharmacy retail franchising industry. The US based investor - Pacific Gateway Capital LLP took eight years in researching the Chinese pharmacy market, and finally, Pacific Gateway Capital LLP set up a joint venture with Chinese partner Shenzhen Nep-Star Enterprise.

Second, Taiwanese Investors are increasing their investment in China.

About twice as many Taiwanese investors are planning to increase their investments in China than in their home country after both sides join the World Trade Organization (WTO). ${ }^{\text {lxiv }}$ Taiwanese investors have invested billions of dollars into China, hoping that with the smoothing over of political disputes between Taiwan and the People's Republic of China, they can enjoy the huge Chinese market, cheaper labor, abundant higher level human resources, and relatively higher return on investments without bearing the political risks there once were. ${ }^{\text {Ixv }}$

Third, domestic private investors are more and more interested in franchising industries.

China now has personal deposits surpassing 8 trillion yuan (US\$966 billion) now. ${ }^{\text {lxvi }}$ If these Chinese investors want to investment their deposits into foreign pharmaceutical franchise, it would be a big source for the capital.

According to a survey on the 2002 national economy, one third of GDP is generated by state-owned facilities; the remaining two-third of GDP came from the private-owned economy. ${ }^{\text {lxvii }}$ The Investment Research Institute predicted that the growth rate of the Chinese private capital would be as high as $24.8 \%$ in $2005^{\text {lxviii }}$. This trend shows that private ownership will play a more important role in China's business development. With such a prosperous industry, Chinese private investors will fully utilize their advantages in the Chinese market by using franchise model. 
In the Chinese capital market, one of the biggest barriers for foreign investors is that the Chinese capital market is not flexible enough; therefore, foreign investors may encounter difficulties in getting into Chinese market by using acquisition and merger method. ${ }^{\text {lxix }}$

\section{Current Legal Environment in China}

China has improved its legal environment since it opened the door to the world since the 1980's. However, the progress is not completed enough to protect investors benefits and rights. The following two cases shows how legal problems occurred and how the issues were solved.

\section{Case 1. Pepsi and Sichuang Pepsi}

Pepsi has been entered into the Chinese market for over 20 years. During these years, most of the cooperation is very successful. However, Pepsi began to have a dispute with its Sichuang Chengdu's partner. To solve the dispute, on August $2^{\text {nd }}, 2002$, Pepsi requested for arbitration on the termination of the cooperation between Pepsi and Sichuang Chengdou Company. Although the dispute is still processing, Pepsi's CEO said that he was very happy to see that the dispute would be solved through the legal method in China, and it was really a good sign for all foreign investors. ${ }^{1 \times x}$

\section{Case 2. A\& W and Ai De Wei Beijing Corporation}

In September 1996, A\&W Restaurant group signed a contract with Ai De Wei Beijing Corporation. By contract, Ai De Wei got the right to operate fast food restaurants as a franchisee. Ai De Wei has opened eight stores in Beijing since then. At the end of 2000, Ai De Wei began to delay the payment of its franchise fee. According to the contract, A \& W terminated the franchise contract with Ai De Wei in January 2002. However, Ai De Wei never stopped its operation under the A \& W's name. Although A \& W has tried to negotiate with Ai De Wei several times, both parties have not reach any resolutions due to Ai De Wei's breach of contract so far. . $x x i^{-}$

These cases show that the Chinese government has set up laws to protect franchisers and franchisees. US franchisers have to be very prudent when drawing up franchise contracts, and must make contracts as details as much possible, so that whenever an issue arises, one party can make the party that breaches the contract take responsibility.

\section{Conclusion}

China has a huge retail pharmacy market and the on-going medical reforms will make the retail pharmacy industry even more attractive. Pharmaceutical franchising retail in China is still in the infant stage, which gives American franchisers more opportunities. As in the case of the Medicine Shoppe, U.S. retail pharmaceutical franchising companies need to focus on prescription drugs, service and information technology management in order to optimize its advantages.

Although the case of the Medicine Shoppe is an example of a complex industry, the lessons from Medicine Shoppe can be applied to many franchising industries.

First, select a suitable strategy when entering the Chinese market. There are three entry strategies available for foreign franchisers: franchising/licensing, wholly owned subsidiary, and joint venture ${ }^{\text {lxxii }}$. In the Medicine Shoppe case, the company utilized the third option - joint venture. By using the joint venture strategy, Medicine Shoppe found a very powerful Chinese partner that helped it expand business in China more easily and faster than its competitors.

Second, use the first mover strategy. China's registration system for trademarks is on a "first-to-file" basis, therefore it is important for foreign franchisers to register their trademarks in China as quickly as they can ${ }^{\text {lxxiii. In }}$ 
order to be successful in China's franchising industry, foreign franchisers that want to expand abroad do not have to be a big enterprise in the U.S., as long as they choose suitable strategies for the Chinese market. For example, Medicine Shoppe has only a few stores in the U.S., however, because it set up the first pharmaceutical franchise store in China, it has become a standout in the Chinese market.

Foreign franchisers should make sure that they file all the contracts between franchisers and franchisees, as well as getting approvals from related authorities in China. Failure to do so may result in lack of legal protection from the Chinese government. China is removing barriers that hinder the registration procedures. The National Pharmacy Administration Bureau has removed 20 out of 70 projects from its approval lists, making registration procedure in China more efficient ${ }^{\mathrm{lxxiv}}$.

Third, build a unique image. Medicine Shoppe emphasized its "100\% pharmacy" when it first arrived in China, providing continuous professional service. At each location, Medicine Shoppe provides certified on-site pharmacy technicians. ${ }^{1 \times x v}$. Many experts believe that Medicine Shoppe will lead the restructuring of the retail pharmacy industry in China.

The fourth lesson is to use local strategies. To be successful in the Chinese market, foreign franchisers have to use local strategies such as local market, local competition, local structure, local products, local partners, and local supplies. ${ }^{\text {lxvi }}$ As Medicine Shoppe China shows, a combination of western and eastern services has created an advantage for Medicine Shoppe to compete with its rivals.

Fifth, screen franchisees' backgrounds. One of the most important lessons Medical Shoppe learned is to screen potential franchisees and find a qualified partner because China has not set up credit system. Many resources are available for foreign franchisers now. For instance, China Chain Store \& Franchise Association (CCFA), the largest nation wide franchise association, provides data on the top franchising enterprises in China and it helps foreign franchisers to understand the Chinese franchising industry and franchising enterprises ${ }^{\text {lxxvii }}$. Prior to 2003, CCFA has successfully sponsored four Chinese Franchising Conferences \& Exhibits. (www.ccfa.org.cn ) The Fifth Chinese Franchising Conference \& Exhibits will be held in October 2003 in Wuhan, China.

In conclusion, as the Medicine Shoppe case shows, franchising in China is a business model that has proved to be very successful, and will become more and more favorable for Chinese and foreign investors. Foreign franchisers and investors should enter into the Chinese franchising industries by using its management experience as part of its globalization strategy.

\section{References:}

${ }^{i}$ Franchising China. http://www.chinalaw.cc/FAQ/faq/F.htm

ii Implication for Global E-Commerce Using Franchising as the Growth Strategy. http://www.bus.lsu.edu/academics/entrepreneurial/franchiseclass/pages/DataMining/GlobalECom.htm

iii KFC opens over 800 outlets in China, Xinhua News Agency, Feb 17, 2003 ( Chinese language)

${ }^{\text {iv }} \mathrm{KFC}$ smiles at Beihai Park. http://www.ultrachina.com/english/doc.cfm?OID=494

${ }^{v}$ Select the right US franchise Concept for Your Business. http://www.buyusa.gov/canada/en/page36.html

${ }^{v i}$ International growth of US Franchising: Cultural and legal barrier. By Hawkes \& Bandyopadhay. 2001. http://www.sbaer.uca.edu/Research/2001/ACME/106acme01.htm

${ }_{\text {vii }}$ Cultural determinants of international franchising: An Empirical Examination of Hofsteds Cultural Dimensions. By Toncar, Alon and Mckee. http://marketing.byu.edu/htmlpages/ccrs/proceedings99/toncar.htm

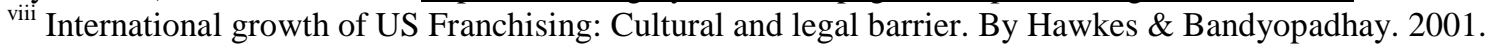
http://www.sbaer.uca.edu/Research/2001/ACME/106acme01.htm

${ }^{\mathrm{ix}}$ Franchising - Best Prospect 2003. http://www.buyusa.gov/france/en/page207.html

${ }^{\mathrm{x}}$ http://www.medicineshoppe.com/

${ }^{x i}$ Realize your dream today. http://www.futureofpharmacy.com/ 
xii Why pharmacy chain stores couldn't change the medical systems? http://www.yzdsb.com.cn/20021115/ca187621.htm (Chinese language only)

xiii http://www.hangzhou.com.cn/20020127/ca201748.htm (Chinese language only)

${ }^{x i v}$ Franchisation in China in the ascendant. Http://www.ultrachina.com/English/doc.cfm?OID=187 (Chinese language only)

${ }^{\mathrm{xv}}$ The Notice of Chain Stores Registration Administration http://page.china.alibaba.com/bin/servlet/page/static/4channel/guide/agent_rule03 (Chinese language only)

${ }^{x v i}$ The Notice of Chain Stores Registration Administration http://page.china.alibaba.com/bin/servlet/page/static/4channel/guide/agent_rule03

${ }_{\text {xvii }}$ Preliminary conditions to become McDonald's franchisees: US $\$ 300,000$. to open a franchise store in China. http://www.haolitong.net/fds/new/new13.htm (Chinese language only)

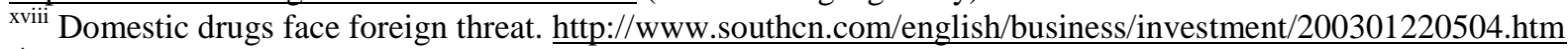

${ }^{x i x}$ Pharmaceuticals. http://www.buyusa.gov/china/en/pharmaceuticals.html

${ }^{x x}$ A Mo Ling: The marketing concept transition of Chang Ao Pharmaceutical. Chinese Medical Newspaper. April 25, 2003. www.sina.net

xxi NewsEdge, June 26, 2002 http://www.nacds.org/wmspage.cfm?parm1=2818

xxii The well developed trend for Chinese pharmaceutical industry. April 18 2003. www.sina.com.cn (Chinese language only)

xxiii The well developed trend for Chinese pharmaceutical industry. April 18 2003. www.sina.com.cn (Chinese language only)

xxiv Hua Bei Pharmaceutical and Wu Han Jun Da Group merges. Feb 17 2003. Economic Observation Daily. www.sina.com.net

${ }_{\mathrm{xxv}}$ Ya Tai Medical and Pharmaceutical Group. April 25, 2003.

http://news1.jrj.com.cn/news/2003-04-25/000000551571.html

${ }_{\mathrm{xxvi}}$ Hua Yuan Group: The picture of reorganization in pharmaceutical industry.

http://news1.jrj.com.cn/news/2002-08-22/000000399744.html

${ }_{\text {xxvii }}$ Hua Yuan Group: The picture of reorganization in pharmaceutical industry. http://news1.jrj.com.cn/news/2002-08-22/000000399744.html

xxviii Shenzhen 999 and Japanese 89 Jun Zhe agreed to build pharmaceutical chain stores in China soon. Xinhua News. http://www.cpu.edu.cn/Upload/2003317807750.htm

${ }_{\text {xxix }}$ A survey on the top pharmacy chain stores in China in 2002. Xinhua News. March, 2003.

http://www.xinbang.com/news/news.asp?id=415 (Chinese language only)

${ }_{\mathrm{xxx}}$ Medicine Shoppe - Franchising project in China. Stardrugs News.http://www.stardrug.com.cn/news/news56.htm (Chinese language only)

${ }^{x x x i}$ Shenzhen Medicine Shoppe got the first ISO 9001 in China in the pharmacy industry. http://www.stardrug.com.cn/news/news46.htm (Chinese language only)

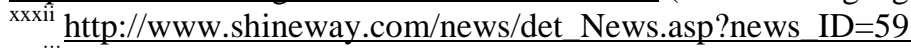

xxxiii The Chinese and foreign retailer of pharmacy are competing in the Chinese market.

http://www.pharmnet.com.cn/news-s/03/2003-03-24/00000566.html

${ }_{\text {xxxiv }}$ Professional pharmacy: New trend in China? Zhengwu Liu.

http://www.pharmnet.com.cn/news-s/02/2002-10-22/00047137.html (Chinese language only)

${ }^{\mathrm{xxxv}}$ Why 999 and Huayuan gave up the plan of "opening 10000 chain stores in China"?

http://www.bjbusiness.com.cn/20030114/shijian5.htm (Chinese language only)

xxxvi The conference of the Chinese retail pharmacy industry.

http://www.sas-china.com/yantaohui/shwl/zhuanti_nfds2.htm (Chinese language only)

xxxvii Beijing is seeing fierce competition in the retail pharmacy industry. The newspaper of the Chinese Finance. http://finance.21dnn.com/26/2002-5-17/166@246926.htm (Chinese language only)

xxxviii Medicine Shoppe set up first store in Shanghai. Oriental News Net. March 2003.

http://jk.qd.sd.cn/Professional/drugg/200303/15294120030331.htm (Chinese language only)

${ }_{\text {xxxix }}$ Medicine Shoppe - Franchising project in China. Stardrugs News.

http://www.stardrug.com.cn/news/news56.htm (Chinese language only) 


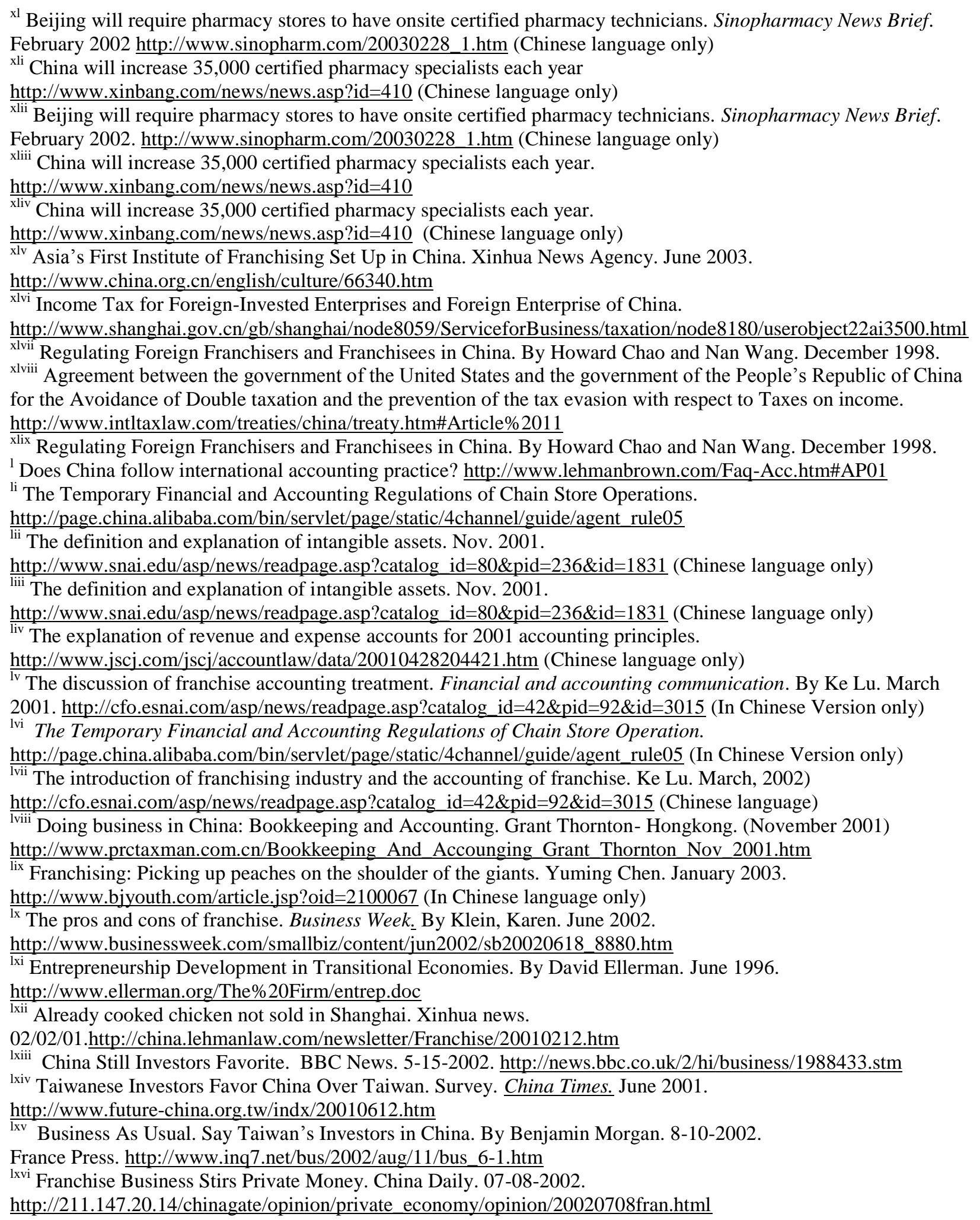


${ }^{1 x v i i}$ China's Private Capital to Boom. 2-24-2003. China Daily. http://211.147.20.14/chinagate/opinion/private economy/opinion/20030224boom.html

${ }^{1 x v i i i}$ State, Private Investment To Rise in China, While Foreign Investment Falls. http://www.chinavista.com/business/news/archive/20mar/mar10-03.html

${ }_{\text {Ixix }}$ Foreign capital eyes on the retail pharmacy market in China. The Newspaper of Marketing. October 2002. http://www.snweb.com/gb/market_daily/2002/10/21/k1021004.htm (Chinese language only)

${ }_{\mathrm{Ixx}}$ Sichuang Chengdou Pepsi. The newspaper of international business. October 2002. http://finance.sina.com.cn/b/20021008/1203263057.html (Chinese language only)

${ }^{1 \times x i}$ Ai De Wei is operating A \& W's brand without any authorization. April 2003. http://www.longhoo.net/gb/longhoo/news/economy/node102/userobjectlai48717.html\#b252256 (Chinese language only)

lxxii KFC in China - A Case Study. By Johans. http://www.geocities.com/TimesSquare/1848/kfc.html

${ }^{1 x x i i i}$ Legal issues related to Franchising in China. By Fraser Mendel. http://www.sinofranchise.com/articles/regulatory framework.html

${ }^{1 x x i v}$ The Chinese Pharmacy Administration Bureau Canceled 20 projections from its approval lists. The Chinese Medical and Pharmacy Newspaper. Nov 17 2002. http://www.satcm.gov.cn/lanmu/zhongyao/20-shenpi.htm (Chinese language only)

${ }^{\text {Ixxv }}$ Medicine Shoppe Entered Guangzhou, China. http://www.stardrug.com.cn/news/news69.htm (Chinese language only)

${ }^{\text {Ixxvi }}$ Global thinker, local marketer. By P. Hallutt and M. Truman. http://www.sinofranchise.com/articles/franchise strategy.html

Ixxvii $\underline{\text { http://www.ccfa.org.cn/index.jsp }}$

$\underline{\text { Notes }}$ 
$\underline{\text { Notes }}$ 